\title{
Identifying and Analysing the Drivers of Heterogeneity among Ecosystem Builder Accelerators
}

Prexl, Katja-Maria; Hubert, Marco; Beck, Susanne; Heiden, Christian; Prügl, Reinhard

Document Version

Accepted author manuscript

Published in:

$\mathrm{R} \& \mathrm{D}$ Management

DOI:

10.1111/radm.12352

Publication date:

2019

License

Unspecified

Citation for published version (APA):

Prexl, K-M., Hubert, M., Beck, S., Heiden, C., \& Prügl, R. (2019). Identifying and Analysing the Drivers of Heterogeneity among Ecosystem Builder Accelerators. $R$ \& D Management, 49(4), 624-638.

https://doi.org/10.1111/radm.12352

Link to publication in CBS Research Portal

\section{General rights}

Copyright and moral rights for the publications made accessible in the public portal are retained by the authors and/or other copyright owners and it is a condition of accessing publications that users recognise and abide by the legal requirements associated with these rights.

\section{Take down policy}

If you believe that this document breaches copyright please contact us (research.lib@cbs.dk) providing details, and we will remove access to the work immediately and investigate your claim.

Download date: 26. Apr. 2023
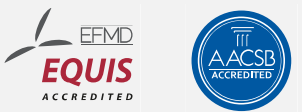


\title{
Identifying and Analysing the Drivers of Heterogeneity among Ecosystem Builder Accelerators
}

\section{Katja-Maria Prexl, Marco Hubert, Susanne Beck, Christian Heiden, and Reinhard Prügl}

\author{
Journal article (Accepted manuscript*)
}

\section{Please cite this article as:}

Prexl, K-M., Hubert, M., Beck, S., Heiden, C., \& Prügl, R. (2018). Identifying and Analysing the Drivers of Heterogeneity among Ecosystem Builder Accelerators. $R \& D$ Management.

https://doi.org/10.11l1/radm.12352

This is the peer reviewed version of the article, which has been published in final form at DOI:

https://doi.org/10.1111/radm.12352

This article may be used for non-commercial purposes in accordance with

Wiley Terms and Conditions for Self-Archiving

* This version of the article has been accepted for publication and undergone full peer review but has not been through the copyediting, typesetting, pagination and proofreading process, which may lead to differences between this version and the publisher's final version AKA Version of Record. 


\section{Identifying and analysing the drivers of heterogeneity among corporate accelerator programmes}

\section{ABSTRACT}

In response to convergent and dynamic market developments, established firms use corporate accelerators to open their innovation processes to start-ups. Research on this strategic open innovation approach is gaining importance, but it remains scarce and fragmented. To support a more detailed view of accelerator programmes, we investigate one specific theme of accelerators: the "ecosystem builder," as introduced by Pauwels et al. (2016). We argue that heterogeneity exists among different corporate accelerator programmes within the ecosystembuilder based on differences in the process of selection, business support, and graduation. This heterogeneity is reflected in different corporate accelerator types within the ecosystem builder theme. We interviewed 20 leading experts from 16 German corporate-accelerator programmes and identified five types within the ecosystem builder theme. These types show important differences and similarities in terms of strategies, design elements, and processes. Thus, by categorizing programmes into these five types, we reduce the complexity for incumbents using the open innovation strategy to access the start-up ecosystem.

Key Words: Ecosystem Builder Types, Corporate Accelerator Programmes, Corporate Accelerator Heterogeneity, Start-up Supporting System, Open Innovation 


\section{INTRODUCTION}

Driven by the challenges of dynamic market environments (e.g., in the context of digitalization) and the necessity of staying innovative, companies are opening up their internal innovation processes to profit from external knowledge sources like start-ups (Enkel et al., 2009; Gassmann et al., 2010). Therefore, established companies have started launching corporate venture capital, corporate incubation, and corporate accelerator programmes to foster structured interaction with start-ups (Weiblen \& Chesbrough, 2015).

Accelerator programmes are time-limited forms of external/internal cooperation and are used for certain stages of start-ups (e.g., mature, early-, and late-stage) (Weiblen \& Chesbrough, 2015). They are the next evolutionary step towards implementing start-upsupporting strategies (Cohen, 2013; Hochberg, 2016; Isabelle, 2013; Miller \& Bound, 2011; Pauwels et al., 2016). Although there is important research on the strategies, design elements, and processes of corporate start-up engagement using corporate venture capital programmes (e.g., Benson \& Ziedonis, 2009; Bruneel et al., 2012; Grimaldi \& Grandi, 2005; Weiblen \& Chesbrough, 2015) and incubator programmes (e.g., Allen \& McCluskey, 1990; Bergek \& Norrman, 2008; Hackett \& Dilts, 2004), few academic studies have analysed corporate accelerator programmes (e.g., Barbero et al., 2014; Bauer et al., 2016; Kohler, 2016; Weiblen \& Chesbrough, 2015).

Pauwels et al. (2016) were one of the first to investigate and structure accelerator programmes by analysing characteristics and drivers using a design lens (i.e., programme package, strategic focus, selection process). They identified three types of accelerator programmes: (1) the ecosystem builder, which focuses on corporations and the corporate environment; (2) the deal-flow maker, which focuses on investor funding and venture capital; and (3) the welfare stimulator, which focuses on the generalist local and/or international level and has government agencies as its main stakeholders.

The present study builds upon the pioneering investigation of design themes and focuses on the ecosystem builder as a design theme strongly related to (traditional) corporate start-up engagement (Pauwels et al., 2016; Weiblen \& Chesbrough, 2015). 
Prevailing research demonstrates the necessity of combining external and internal knowledge especially in corporate innovation processes (Gassmann et al., 2010) to increase corporate engagement and to integrate a start-up culture characterised by speed, flexibility, and risk-taking (Weiblen \& Chesbrough, 2015). Corporate willingness and openness to increase innovation and accept risks has led to diversified corporate ecosystem builder activities aiming to increase their agility and to leverage corporate experience, knowledge, infrastructure, and networks (Oh et al. 2016, Weiblen \& Chesbrough, 2015). Therefore, corporate accelerators are the next evolutionary step after corporate incubators which in consequence increase the importance of understanding the ecosystem builder as such (Pauwels et al., 2016; Weiblen \& Chesbrough, 2015).

However, observing a dynamic environment of individualized programmes of corporate engagement and considering the recent growth of corporate accelerators (Heinemann, 2016), we question the homogeneity of this design theme and assume diverse typologies within the ecosystem builder theme based on different strategies and processes. In more detail, we deem it necessary to explore and structure the heterogeneity of accelerator programmes within the ecosystem builder design theme of accelerators to maintain the strategic usefulness of this open innovation approach for both incumbents and start-ups. We interviewed 20 leading experts from 16 German corporate accelerator programmes that can be characterized as ecosystem builders (1) to deepen the understanding of the similarities and differences in their strategies, design elements, and processes of corporate accelerator programmes (Pauwels et al., 2016; Wise \& Valliere, 2014) and (2) to identify and analyse types of corporate accelerator programmes associated with the ecosystem builder (Pauwels et al., 2016).

This article is structured as follows. The next section outlines the theoretical background of corporate accelerator programmes. It is followed by the methodological procedure used to identify five corporate accelerator types within the ecosystem builder accelerator theme. Then, we discuss the resulting implications to guide incumbents' choices for accelerator programmes to mutually benefit from cooperating with start-ups. The article 
concludes with an overall discussion as well as limitations highlighting future research opportunities.

\section{THEORETICAL BACKGROUND OF CORPORATE ACCELERATORS}

\section{Start-up-Supporting Activities and Corporate Accelerators}

Weiblen \& Chesbrough (2015) identified three major success factors that corporations need to consider when engaging with start-ups: (1) their absorptive capacity and ability to work with numerous start-ups, (2) a clear value proposition for the start-ups, and (3) a clear strategy for the desired benefits for the incumbent corporation. Based on these success factors, they then identified four general models of corporate engagement with start-ups: (1) corporate venture capital, (2) corporate incubation, (3) platform-based start-up programmes, and (4) outside-in start-up programmes (Weiblen \& Chesbrough, 2015). According to this classification of corporate start-up engagement, the corporate accelerator programme is part of the fourth model, the outside-in start-up programme (Weiblen \& Chesbrough, 2015).

Accelerators are time-limited programmes that shift towards intangible, knowledgeintensive support services that typically focus on education and mentoring (e.g., Cohen, 2013; Hochberg, 2016; Isabelle, 2013; Miller \& Bound, 2011). Unlike incubators and venturecapital programmes, accelerators have a high turnover rate of two to three batches of startups per year with comparably short investment cycles, a limited duration of three to six months, differences in the kind of counselling offered, a competitive and cyclical selection process, and an on-site venture location (Bauer et al., 2016; Hochberg, 2016; Pauwels et al., 2016). Furthermore, accelerators downplay physical resources and product development support. Instead, they focus on networking facilitation (Barbero et al., 2014) for young seedstage start-ups, and their investment strategies are more like those of business angels and less like those of large-scale corporate venture capital programmes (Bruneel et al., 2012; Pauwels et al., 2016).

\section{Accelerator Themes}


Accelerators evolved from corporate engagement through incubators (Bruneel et al., 2012; Pauwels et al., 2016). Therefore, the underlying processes of start-up-supporting activities are associated with existing models within the incubation literature (Bergek \& Norrman, 2008). These models are based on a three-step process of different antecedents: selection of start-ups (Bergek \& Norrman, 2008), business support of selected start-ups (e.g., Allen \& McCluskey, 1990; Bruneel et al., 2012; Hackett \& Dilts, 2004; McAdam \& McAdam, 2008; Schwartz, 2013), and graduation (Baum \& Silverman, 2004). This process is mandatory for identifying the main elements of accelerators and helps to systematize corporate accelerator programmes (Bruneel et al., 2012; Pauwels et al., 2016).

Many authors have attempted to integrate and characterize accelerator programmes within the existing landscape of (corporate) start-up engagement (Cohen, 2013; DaSilva \& Gurtner, 2017; Hochberg, 2016; Weiblen \& Chesbrough, 2015), but only a few studies have specifically identified and subsumed a variety of programmes to different themes of (corporate) accelerators (Pauwels et al., 2016). By investigating 13 European accelerator programmes, Pauwels et al. (2016) identified three specific design themes of acceleratorsthe deal-flow maker, the welfare stimulator, and the ecosystem builder-based on differences and similarities in five design elements: programme package, strategic focus, selection process, funding structure, and alumni relations. The deal-flow maker identifies investment opportunities for potential investors and is oriented towards a corporate venturecapital programme. The welfare stimulator combines start-up activity with economic development and typically includes government agencies. The ecosystem builder focuses on a corporation's efforts to match, implement, and align start-ups for establishing a corporate ecosystem; it is thus the design theme to emphasize connection, exchange, and long-term learning in corporations for ongoing corporate development, growth, and disruptive innovation and change.

However, corporate strategies often create heterogeneous selection among as well as within corporate engagement activities (Weiblen \& Chesbrough, 2015). Moreover, different levels of engagement due to corporate restrictions on engagement with external 
actors, for example, or limited resources for efficiently integrating external knowledge (Volberda et al., 2010) can also increase the heterogeneity with a selected corporate engagement strategy. Thus, the majority of research considers the heterogeneity between different types of accelerators (Barbero et al., 2014; Bruneel et al., 2012; Pauwels et al., 2016), and research on possible heterogeneity within different types of accelerators is scarce (Cohen, 2013; Hochberg, 2016). To build upon this pioneering research, scholars should further structure and characterize corporate accelerator programmes (Bergek \& Norrman, 2008; Mian et al., 2016; Pauwels et al., 2016). Thus, we stress the importance of investigating the rapid developments and the increasing individualization of engagement in this area.

Assumption 1: There exists heterogeneity among different corporate accelerator programmes based on differences in the three-step process of selection, business support, and graduation.

Assumption 2: The heterogeneity among different corporate accelerator programmes leads to different types within the ecosystem builder theme.

\section{METHOD AND RESEARCH DESIGN}

We chose an inductive, multiple-case study design (Eisenhard \& Graebner, 2007; Pauwels et al., 2016). To avoid common-method bias (Miller \& Bound; 2011; Pauwels et al., 2016; Weiblen \& Chesbrough, 2015), each case includes data from multiple sources: (1) expert interviews, (2) additional internal information provided by the interviewees, and (3) publicly available data.

\section{Sample}

To observe heterogeneity among different accelerators, we kept the external context as homogeneous as possible (Welter, 2011). Thus, we limited our sample collection to a single country (Germany). We applied the following six key factors to identify potential 
corporate accelerators that follow the strategic goal to build an ecosystem, provide innovation opportunities (ecosystem builder, according to Pauwels et al., 2016), and differentiate them from incubation programmes: (1) possible upfront investment $(€ 10 \mathrm{k}-€ 50 \mathrm{k})$ and possible exchange for equity ( 5-10\%), (2) time-limited support, (3) a highly competitive application process that is open to all, (4) cohorts of start-ups, (5) a focus on small teams, and (6) periodic graduation with a demo day or investor day (Pauwels et al., 2016). Overall, we identified 67 programmes and corporations and contacted them through an official letter inviting them to join the study. The final sample consists of 16 German corporate accelerators operating in various industries (Table 1 summarizes the characteristics and specifications of the sample), which are all categorized as ecosystem builders (Pauwels et al., 2016).

Table 1: Sample characteristics and specifications

\begin{tabular}{|c|c|c|c|c|c|c|}
\hline Case & $\begin{array}{l}\text { Founding } \\
\text { Year }\end{array}$ & $\begin{array}{l}\emptyset \text { Age of } \\
\text { Participating } \\
\text { Start-ups } \\
\text { (in months) } \\
\end{array}$ & $\begin{array}{l}\emptyset \text { Financial } \\
\text { Support for } \\
\text { Each Start-up }\end{array}$ & $\begin{array}{l}\text { Equity in } \\
\text { Exchange }\end{array}$ & $\begin{array}{l}\text { \% Share of Successful } \\
\text { Follow-on Investments } \\
\text { (\% of Internal } \\
\text { Investment) }\end{array}$ & $\begin{array}{l}\text { Batches per year } \\
\text { (Duration in } \\
\text { Months) }\end{array}$ \\
\hline 1_Car & 2015 & $\min .6-12$ & flexible & none & none (none) & flexible (4) \\
\hline 2_Car & 2015 & $6-12$ & $€ 25,000$ & $5 \%$ & $n / a(n / a)$ & $2(3)$ \\
\hline 3_Bank & 2014 & $\max .6$ & flexible & varying & $\mathrm{n} / \mathrm{a}(\mathrm{n} / \mathrm{a})$ & flexible (varying) \\
\hline 4_Retail & 2014 & $3-12$ & $\begin{array}{l}€ 20,000 \\
(+€ 100,000 \\
\text { convertible debt } \\
\text { note possible) } \\
\end{array}$ & $7-10 \%$ & $\mathrm{n} / \mathrm{a}(\mathrm{n} / \mathrm{a})$ & $1-2(3)$ \\
\hline 5_Pharma & 2013 & $6-12$ & $€ 50,000$ & $<10 \%$ & $\mathrm{n} / \mathrm{a}(\mathrm{n} / \mathrm{a})$ & $1-2(4-6)$ \\
\hline 6_Finance & 2013 & $\min .6-12$ & flexible & varying & $\mathrm{n} / \mathrm{a}(\mathrm{n} / \mathrm{a})$ & $2-3(\max .6)$ \\
\hline 7_IT & 2010 & $\max .6$ & $€ 15,000$ & None & $\begin{array}{l}20-60 \% \\
(10-20 \%)\end{array}$ & no batches \\
\hline 8_IT & 2013 & $\max .6$ & none & $n / a$ & $\begin{array}{l}60-90 \% \\
(<10 \%)\end{array}$ & flexible (6-9) \\
\hline 9_IT & 2012 & $0-12$ & flexible & varying & customized (n/a) & flexible (3-6) \\
\hline 10_Media & 2014 & $6-12$ & $€ 50,000$ & $5 \%$ & $\begin{array}{l}100 \% \\
(0 \%)\end{array}$ & $1(6-9)$ \\
\hline 11_Media & 2013 & $6-18$ & $€ 25,000$ & None & $\begin{array}{l}100 \% \\
(0 \%) \\
\end{array}$ & $2(3)$ \\
\hline 12_Transport & 2015 & $3-12$ & $€ 25,000$ & None & $\mathrm{n} / \mathrm{a}$ & $2(3)$ \\
\hline 13_Tech & 2014 & $0-12$ & flexible & varying & $\mathrm{n} / \mathrm{a}$ & flexible (varying) \\
\hline 14_Tech & 2016 & $\max .6$ & flexible & varying & $\mathrm{n} / \mathrm{a}$ & $2-3(2-3)$ \\
\hline 15_Phone & 2012 & $6-12$ & $\begin{array}{l}€ 100,000- \\
€ 300,000\end{array}$ & $10-15 \%$ & $\begin{array}{l}80-100 \% \\
(0 \%)\end{array}$ & flexible (varying) \\
\hline 16_Phone & 2013 & $6-12$ & $\max . € 50,000$ & $5-10 \%$ & $\begin{array}{l}80-100 \% \\
(0 \%)\end{array}$ & $2(3)$ \\
\hline
\end{tabular}

\section{Data Acquisition}


In-line with Irvine et al. (2013), two independent researchers conducted 20 face-to-face interviews (30 to 90 minutes long) in German and English between August 2014 and June 2016. Each interview was tape-recorded, transcribed, and completed with internally and publicly available information (McLellan et al., 2003). This information includes company websites, news articles about the organizations and programmes, annual reports, media coverage, and company and programme presentations. This resulted in 388 pages of transcripts.

\section{Interview Guideline}

We followed a semi-structured interview guideline based on Bernard \& Bernard (2012) to provide clear instructions and gain reliable qualitative data from the interviews. The guideline was translated, retranslated, and pretested and then arranged in five sections: (1) basic programme data (e.g., number of batches); (2) questions about the selection process (Bergek \& Norrman, 2008); (3) questions about business-supporting and value-adding services (e.g., provision of infrastructural services, professional business support; Bruneel et al., 2012; Rice, 2002; Vanderstraeten \& Matthyssens, 2012); (4) questions about collaborative projects between start-ups, the accelerator enterprise, and other strategic partners (e.g., Benson \& Ziedonis, 2009; Cohen \& Levinthal, 1990; Grimaldi \& Grandi, 2005); and (5) questions about the programme's graduation process, exit policy, and long-term perspective (Baum \& Silverman, 2004; Stuart et al., 1999).

\section{Data Analysis}

The data were summarized and interpreted using the text-reduction method (Bernard \& Bernard, 2012). The process applied by Weiblen \& Chesbrough (2015) and Pauwels et al. (2016) was adapted slightly, and two researchers extracted the data separately. An independent researcher participated in the analysis for greater validity of the interpretations (Gioia et al., 2010). A cross-case analysis (Eisenhardt, 1989) identified patterns and revealed differences among the interviews (Table 2 shows the procedure in more detail).

Table 2: Overview of data analysis 


\begin{tabular}{|c|c|c|}
\hline \multirow{2}{*}{$\begin{array}{l}\text { Step 1: } \\
\text { Preparation of } \\
\text { Data and First } \\
\text { Steps of } \\
\text { Analysis }\end{array}$} & Step 1a & $\begin{array}{l}\text { Interviews and external data (company websites, news articles about } \\
\text { the organizations and programmes, annual reports, media coverage, and } \\
\text { additional information provided by the interviewees ). }\end{array}$ \\
\hline & Step $1 b$ & $\begin{array}{l}\text { Recording and transcribing the interviews. } \\
\text { Merging and interpreting the main characteristics (context and } \\
\text { case): } \\
\text { 1. Constructing a matrix for the interview guidelines. } \\
\text { 2. Completing the case overview with additional information. }\end{array}$ \\
\hline \multirow{2}{*}{$\begin{array}{l}\text { Step 2: } \\
\text { Identifying } \\
\text { Relevant } \\
\text { Statements and } \\
\text { First Structure }\end{array}$} & Step 2a & $\begin{array}{l}\text { Coding key phrases and patterns of meaning iteratively (Spiggle, } \\
\text { 1994) within several rounds. }\end{array}$ \\
\hline & Step $2 b$ & $\begin{array}{l}\text { Structuring content analysis: Identifying relevant statements } \\
\text { (Bernard \& Bernard, 2012): } \\
\text { 1. Context-related statements to interview categories of the } \\
\text { interview guidelines (function, dimension/theory, and questions). } \\
\text { 2. Advanced completion of matrix. } \\
\text { 3. Identifying provisional codes and categories. } \\
\text { 4. Identifying related statements with significant difference to } \\
\text { company and programme. }\end{array}$ \\
\hline \multirow[t]{3}{*}{$\begin{array}{l}\text { Step 3: } \\
\text { Selection, } \\
\text { Comparison, } \\
\text { Definition, and } \\
\text { Evaluation Grid }\end{array}$} & Step 3a & $\begin{array}{l}\text { Cross-Case Analysis (Eisenhardt, 1989): Selection, Comparison, and } \\
\text { Verification: } \\
\text { 1. Recording differences and similarities. } \\
\text { 2. Main characteristics merged and interpreted with respect to the } \\
\text { context of our problem description. } \\
\text { 3. Repeating the process and merging results. } \\
\text { 4. Defining the evaluation grid with categories and elements. } \\
\text { 5. Entering the identified and corresponding data. }\end{array}$ \\
\hline & Step $3 b$ & $\begin{array}{l}\text { Defining categories, elements, and values using three-step process } \\
\text { (Bergek \& Norrman, 2008): } \\
\text { 1. Inter-case similarities and differences. } \\
\text { 2. Categories and dimensions suggested by elements and } \\
\text { constructs from each interview grid over all cases, followed by } \\
\text { comparison and replication against one another (Yin, 2013). } \\
\text { 3. Finally, enter date completed in the evaluation grid. }\end{array}$ \\
\hline & Step 3c & $\begin{array}{l}\text { Advancement towards categories in the evaluation grid: } \\
\text { 1. Comparative analysis to cluster in various rounds (Miles \& } \\
\text { Huberman, 1994). } \\
\text { 2. Identifying and defining category and element relationships. } \\
\text { 3. Pooling the different categories and elements and refining } \\
\text { evaluation grid (Tables } 2 \text { and 3). }\end{array}$ \\
\hline \multirow{3}{*}{$\begin{array}{l}\text { Step 4: } \\
\text { Advancement } \\
\text { towards Types } \\
\text { of Corporate } \\
\text { Accelerators } \\
\text { Programmes }\end{array}$} & & $\begin{array}{l}\text { Advancement towards different corporate ecosystem builder } \\
\text { themes with differently sized groups of corporate accelerator } \\
\text { programmes by pooling the categories. }\end{array}$ \\
\hline & Step 4a & $\begin{array}{l}\text { Defining and naming the types by revealed relationships of categories } \\
\text { and elements of cases. }\end{array}$ \\
\hline & Step $4 b$ & $\begin{array}{l}\text { Identifying similarities between and relationships with Pauwels et } \\
\text { al.'s (2016) ecosystem builder theme. }\end{array}$ \\
\hline
\end{tabular}

\section{RESULTS}

\section{Selection, Business Support, and Graduation}

Based on the interview data, we identified and categorized the characteristics of the three steps of selection, business support, and graduation representing also the startingpoint of our typology. The categories of the selection process were (1) acquisition strategy, 
(2) exclusivity, and (3) admission screening. Business support was divided into (1) provision of space and infrastructure, (2) completeness of start-up support (e.g., absence or presence of different forms of counselling), (3) degree of standardization, and (4) interaction with the corporation (e.g., industry focus, direction of innovation flow). The graduation categories were (1) the presence or absence of predefined time schedules and (2) graduation events (see Table 3 for results).

Table 3: General results for the categories and characteristics of the three-step process

\begin{tabular}{|c|c|c|c|}
\hline $\begin{array}{l}\text { Process } \\
\text { Step }\end{array}$ & Category & Characteristic & $\begin{array}{l}\text { Count } \\
\text { (\% of the } 16 \\
\text { programmes) }\end{array}$ \\
\hline \multirow{6}{*}{ Selection } & \multirow{2}{*}{ Acquisition Strategy } & Open-to-all & $81 \%$ \\
\hline & & Focused & $19 \%$ \\
\hline & \multirow[t]{2}{*}{ Exclusivity } & Yes & $31 \%$ \\
\hline & & No & $69 \%$ \\
\hline & \multirow[t]{2}{*}{ Admission Screening of New Start-ups } & Picking-the-winners & $63 \%$ \\
\hline & & Survival-of-the-fittest & $38 \%$ \\
\hline \multirow{32}{*}{$\begin{array}{l}\text { Business } \\
\text { Support }\end{array}$} & \multirow{2}{*}{ Provision of Shared Office Space } & Yes & $100 \%$ \\
\hline & & No & $0 \%$ \\
\hline & \multirow[t]{2}{*}{ Provision of Infrastructural Services } & Yes & $100 \%$ \\
\hline & & No & $0 \%$ \\
\hline & \multirow{4}{*}{$\begin{array}{l}\text { Completeness of Start-up Support: } \\
\text { Reactive and Episodic Counselling }\end{array}$} & Internal & $18 \%$ \\
\hline & & External & $13 \%$ \\
\hline & & Both & $69 \%$ \\
\hline & & $\mathrm{n} / \mathrm{a}$ & $0 \%$ \\
\hline & \multirow{4}{*}{$\begin{array}{l}\text { Completeness of Start-up Support: } \\
\text { Proactive and Episodic Counselling }\end{array}$} & Internal & $13 \%$ \\
\hline & & External & $63 \%$ \\
\hline & & Both & $25 \%$ \\
\hline & & $n / a$ & $0 \%$ \\
\hline & \multirow{4}{*}{$\begin{array}{l}\text { Completeness of Start-up Support: } \\
\text { Continuous and Proactive Counselling }\end{array}$} & Internal & $44 \%$ \\
\hline & & External & $50 \%$ \\
\hline & & Both & $0 \%$ \\
\hline & & $\mathrm{n} / \mathrm{a}$ & $6 \%$ \\
\hline & \multirow{5}{*}{$\begin{array}{l}\text { Completeness of Start-up Support: } \\
\text { Hands-on Business Assistance } \\
\text { /Technical Assistance }\end{array}$} & Internal & $25 \%$ \\
\hline & & External & $0 \%$ \\
\hline & & Both & $25 \%$ \\
\hline & & None & $44 \%$ \\
\hline & & $\mathrm{n} / \mathrm{a}$ & $6 \%$ \\
\hline & \multirow[t]{3}{*}{ Degree of Standardization } & Low & $25 \%$ \\
\hline & & Medium & $18 \%$ \\
\hline & & High & $56 \%$ \\
\hline & \multirow[t]{3}{*}{ Focus on Industries } & Vertical & $44 \%$ \\
\hline & & Horizontal & $25 \%$ \\
\hline & & Flexible & $31 \%$ \\
\hline & \multirow[t]{3}{*}{ Integration with Core Business Corporation } & Low & $38 \%$ \\
\hline & & Medium & $38 \%$ \\
\hline & & High & $25 \%$ \\
\hline & \multirow[t]{2}{*}{ Direction of Innovation Flow } & Outside-in & $75 \%$ \\
\hline & & Inside-out & $25 \%$ \\
\hline
\end{tabular}




\begin{tabular}{|l|l|l|l|}
\hline \multirow{4}{*}{} & Value Capture & Equity involvement & $44 \%$ \\
\cline { 3 - 4 } & & Service fees & $0 \%$ \\
\cline { 3 - 4 } & \multirow{2}{*}{ Organizational Anchoring } & None & $56 \%$ \\
\hline \multirow{4}{*}{ Graduation } & & $\begin{array}{l}\text { Separate corporate } \\
\text { identity }\end{array}$ & $50 \%$ \\
\cline { 3 - 4 } & & Project-based & $50 \%$ \\
\cline { 3 - 4 } & Gre-Defined Time Schedule & Fixed-term batch & $50 \%$ \\
\cline { 3 - 4 } & & Flexible-term batch & $50 \%$ \\
\hline & & Yes & $63 \%$ \\
\cline { 3 - 4 } & No & $38 \%$ \\
\hline
\end{tabular}

First, for the selection process, we observed stronger similarities in the acquisition strategy with a focus on open-to-all start-ups (Pauwels et al., 2016). Exclusivity (69\% vs. $31 \%$ of the programmes) and admission screening (63\% vs. $38 \%)$ were relevant antecedents for the assumed heterogeneity among accelerator programmes, even within the ecosystem builder theme (Pauwels et al., 2016). Second, for business support, the positive evaluation of provision of shared office space and infrastructural support was identical in all cases; it seems to be a necessary condition for differentiating accelerators from incubators (e.g., Barbero et al., 2014; Bergek \& Norrman, 2016; Kohler, 2016), but not for distinguishing between ecosystem builder accelerator types. The completeness of start-up support with its different counselling forms showed that continuous and proactive counselling is a main driver of heterogeneity among the ecosystem builder accelerator types.

The other two forms of counselling support were similar, with either no distinction between internal and external forms (proactive and episodic counselling) or a strong focus on external counselling (continuous and proactive counselling). Furthermore, although standardized start-up support and direction of innovation flow are more convenient conditions, with almost identical patterns among accelerator programmes, the important drivers of distinction among accelerator programmes are industrial focus, integration with the corporation's core business, value capture, and organizational anchoring. Third, regarding graduation, both characteristics_-pre-defined time schedule and graduation event-showed a heterogeneous pattern among accelerator programmes. Consequently, these results confirm assumption 1, that there exists heterogeneity among the corporate accelerator 
programmes based on differences in the three-step process of selection, business support, and graduation.

\section{Classifying Corporate Accelerator Programmes into Types}

Based on the derived characteristics (see Table 3) from the analysis (see Table 2), we classified the accelerator programmes into five corporate accelerator types: Start-up Accelerator (SUA), Idea-Lab Accelerator (ILA), Intrapreneurship Accelerator (IPA), VentureClient Accelerator (VCA), and White-Label Accelerator (WLA).

The Start-up Accelerator (SUA) is the dominant type of accelerator programme within our sample, described by six identified corporate accelerator programmes. It continues the incubator-like investment in young ventures, focusing on profitable assets and liquidation events with a stronger, formalized support process and a relatively low risk profile due to the smaller amounts of direct financial investment.

The Idea-Lab Accelerator (ILA) can shape, adopt, and follow new trends and weak signals from early on as part of a market enactment strategy. The ILA is a kind of hands-on activity for enabling new ideas, innovation development, and change. It focuses on very young start-ups and applies a survival-of-the-fittest approach with fewer pre-selective barriers. This type of corporate accelerator is strictly oriented towards enabling innovation from an early stage. It doesn't require seed investment or equity engagement, and its funding structure from corporations describe the ILA mechanisms to accelerate ideas and build innovation ecosystems. The horizontal focus on industries supports the ecosystem builder's strategic focus and the selection process element with more detail, including the different perspectives on the selection steps and the criteria of our support process. The ILA has a relatively low degree of formality, and it abandons the typical batch concept for a steady and flexible fluctuation, adaption, and exchange with start-ups. This is a prominent characteristic of an ecosystem builder aiming to enhance the ideation process of ideas and new impulses and signals, technologies, and business models from both worlds and actors (outside-in and 
inside-out). The graduation process is flexible, having only individual conceptualized graduation events, but its established infrastructure is suitable for building support services.

The Intrapreneurship Accelerator (IPA) is based on the well-known concept of recognizing and developing (radical) innovation (Pinchot, 1985). Its key characteristics are a predominantly inside-out direction of innovation flow, quick access to resources, and highlevel integration with the incumbent's core business. It aims to explore talents and entrepreneurs with the acceleration of employees' start-up ideas and to enable and accelerate innovation from within the incumbent corporation to better leverage existing resources and keep up with the disruption in the respective industries.

The Venture-Client Accelerator (VCA) is typically set up by corporations aiming to be the (exclusive) client or project partner of a relatively mature start-up without focusing on the classical start-up-supporting activities. The VCA becomes the predominant client for the start-up, which is then integrated into the core business and given access to the necessary resources and partner networks. The VCA has a local and international strategic focus and a longer perspective of the cooperation between the start-ups and partners, depending sometimes on a more flexible time schedule.

The White-Label Accelerator (WLA) represents a new, flexible, individual "platform" model for corporations, and it focuses on horizontal industries to build relationships with start-ups. It is a neutral form of the corporate accelerator ecosystem builder theme and is established externally in a separate corporate entity to enable incumbent corporations to profit from the collaboration with start-ups while sparing them the complex set-up procedure. This type of programme is often set up cooperatively with other (consulting) organizations that specialize in developing and executing accelerator programmes, especially platform solutions (e.g., Techstars, Plug-and-Play). See Table 4 for a summary of the accelerator types, associated corporate accelerator programmes, and representative quotes. 
Table 4: Exemplary representative quotes from different corporate accelerator types

\begin{tabular}{|c|c|c|}
\hline Type & $\begin{array}{l}\text { Accelerator } \\
\text { programmes }\end{array}$ & Representative quote from the interviews \\
\hline $\begin{array}{l}\text { Start-up } \\
\text { Accelerator } \\
\text { (SUA) }\end{array}$ & $\begin{array}{l}\text { 1_Pharma, } \\
\text { 10_Media } \\
\text { 11_Media } \\
\text { 12_Transport } \\
\text { 14_Tech } \\
\text { 16_Phone }\end{array}$ & $\begin{array}{l}\text { "Our dream is that, hopefully, they will advise us in the } \\
\text { future, saying what they are interested in, subjects they are } \\
\text { working on themselves, and scenarios that they could } \\
\text { imagine going after. ... Currently, we are seeking interesting } \\
\text { teams, products, and projects and presenting them. ... } \\
\text { Maybe in the future it will be the opposite way" (16_Phone). } \\
\text { "The accelerator seems to be an advanced programme of } \\
\text { incubators, following the same direction towards substantial } \\
\text { relationships and collaboration with start-ups, but with a } \\
\text { lower risk profile and a stronger formalized supporting } \\
\text { process. Close but separated from the corporation daily } \\
\text { business" (1_Pharma). }\end{array}$ \\
\hline $\begin{array}{l}\text { Idea-Lab } \\
\text { Accelerator } \\
\text { (ILA) }\end{array}$ & $\begin{array}{l}\text { 3_Bank } \\
\text { 7_IT } \\
\text { 8_IT } \\
\text { 15_Phone }\end{array}$ & $\begin{array}{l}\text { "Therefore, an accelerator is also good, because you have } \\
\text { a test surface or a kind of test lab. ... They are seen as an } \\
\text { additional opportunity to leverage existing assets and } \\
\text { resources by testing small but promising market } \\
\text { opportunities, as confirmed by the corresponding } \\
\text { corporations. It is here where things get simply tested fast, } \\
\text { and sometimes really simple questions are tested that we } \\
\text { have dealt with for many years already, but nobody ever } \\
\text { just simply tried and developed them" (7_IT). } \\
\text { "Today's start-ups are the partners and clients of } \\
\text { tomorrow. ... The universal goal is mutual learning! ... } \\
\text { Thus, we are of course not exit-oriented but absolutely } \\
\text { innovation-oriented. ... The most important thing we can do } \\
\text { for our products is R\&D. We bring together our techies with } \\
\text { the companies, teams, and individuals, and then they are } \\
\text { working together now and from time to time and beginning } \\
\text { to understand and learn from new technologies.... What we } \\
\text { are doing is technologically agnostic. ... Due to the fact that } \\
\text { we want to discover new, really new technologies, we are } \\
\text { looking for true innovations. In this case we are absolutely } \\
\text { open to observing and working in peripheral areas" (8_IT). }\end{array}$ \\
\hline $\begin{array}{l}\text { Intrapreneurship } \\
\text { Accelerator } \\
\text { (IPA) }\end{array}$ & $\begin{array}{l}\text { 9_IT } \\
\text { 13_Tech }\end{array}$ & $\begin{array}{l}\text { "It is about motivating the employees from within to work on } \\
\text { their ideas, ideas that maybe do not fit into the existing } \\
\text { plans and strategies of the company or existing divisions. } \\
\text { Thus, in terms of the long-term strategy of the company, we } \\
\text { enable the individual employees to develop new business }\end{array}$ \\
\hline
\end{tabular}




\begin{tabular}{|c|c|c|}
\hline & & $\begin{array}{l}\text { ideas for the corporation ... We want to open the mind for } \\
\text { other ways of thinking and doing and building future } \\
\text { potential for new business models" (13_Tech). } \\
\text { "The reference cases enhance the corporate ability of } \\
\text { fostering disruption and to be open for the outside-in } \\
\text { integration of start-ups" (9_IT). }\end{array}$ \\
\hline $\begin{array}{l}\text { Venture-Client } \\
\text { Accelerator } \\
\text { (VCA) }\end{array}$ & $\begin{array}{l}\text { 1_Car } \\
\text { 6_Finance }\end{array}$ & $\begin{array}{l}\text { "Venture Client' represents the 'natural next step in the } \\
\text { evolution of a start-up.' ... We are working together as their } \\
\text { first client and a following mutual collaboration. ... This } \\
\text { constellation allows our employees, partners, and R\&D to } \\
\text { further develop their ideas and/or projects and allow for } \\
\text { openness of the corporation to implement possible } \\
\text { innovation mechanisms and drivers for really changing and } \\
\text { to authorize with more speed" (1_Car). } \\
\text { "We are the predominant client for the start-up, which is } \\
\text { then highly integrated into the core business and has } \\
\text { access to the necessary resources and partner networks on } \\
\text { a highly individualized support and collaboration" } \\
\text { (6_Finance). }\end{array}$ \\
\hline $\begin{array}{l}\text { White-Label } \\
\text { Accelerator } \\
\text { (WLA) }\end{array}$ & $\begin{array}{l}\text { 2_Car } \\
\text { 4_Retail }\end{array}$ & $\begin{array}{l}\text { "We chose this way as a first step to open our innovation } \\
\text { process for external knowledge from start-ups ... to } \\
\text { continuously engage in the development and growth } \\
\text { innovation of our culture and architecture-specific model, } \\
\text { even with the help of a provider and expert in acceleration } \\
\text { programmes ... and yes, their existing contacts to start-ups } \\
\text { and respecting ecosystems in the first step. ... Yes, } \\
\text { separated from our corporation. Not all employees are open } \\
\text { for new developments" (4_Retail). }\end{array}$ \\
\hline
\end{tabular}

In-line with prior rationales for the ecosystem builder design theme, we observed that the identified corporate accelerator types are associated with elements of the ecosystem builder (Pauwels et al., 2016). However, the results also support assumption 2, that is the idea of different types within this specific accelerator theme. While Pauwels et al.'s (2016) design approach identified one ecosystem builder theme, our three-step process approach (selection, business support, and graduation) identifies a fine-grained differentiation among programmes within the ecosystem builder design theme. 
In the selection phase, ILAs, SUAs, and WLAs apply the open-to-all acquisition strategy with fewer pre-selective barriers. This is in contrast to VCAs and IPAs, which follow the focused, single-acquisition strategy. In terms of admission screening, ILAs and IPAs prefer a survival-of-the-fittest approach. SUAs, WLAs, and VCAs, however, follow the picking-the-winners approach, asking for a comprehensive overview of a start-up's business plan, financial situation, and market development and for a first prototype demonstration during the online application process and pitching event. For VCA, corporations prefer experienced start-ups and entrepreneurs.

Regarding business support, the SUAs in our sample provide only continuous and proactive counselling from external sources. Reactive and episodic counselling is offered by the WLAs from external sources and by the ILAs and VCAs from internal sources, and no support is provided by ILAs or IPAs. WLAs and ILAs offer proactive and episodic counselling from external sources, VCAs offer it from internal sources, and IPAs don't offer it at all. For SUAs and WLAs, continuous and proactive counselling is provided by an outsourced partner or entity, and for ILAs, VCAs, and IPAs, it is offered from within the corporation. Technical assistance is offered only by VCAs and IPAs from internal sources, confirming their different characteristics. The degree of standardization of SUAs and WLAs and of these programmes' supporting structures and processes is relatively high; it is medium for ILAs and low for VCAs and IPAs, relating to a flexible and individual time schedule. Regarding the focus on industries, WLAs and ILAs focus mainly on horizontal industries, whereas for VCAs and IPAs, the search for new start-ups focuses on business models and technologies within the market space of the respective incumbent corporation (vertical approach). The industry focus of SUAs varies between vertical and horizontal. Integration in the core business is low for SUAs and WLAs, medium for ILAs, and high for VCAs and IPAs.

The direction of innovation flow is an important indicator for the differences and similarities of the identified types. Only the IPA is characterized by an inside-out orientation; all others focus on the outside-in direction of innovation flow and business development. Regarding value capture, SUAs and WLAs provide financing in exchange for equity to power 
the development and commitment of start-ups. Thus, the degree of equity involvement and operative cooperation is stronger than in all other cases of the ecosystem builder accelerator type. There, the investment logic is driven by a purely strategic approach with no financial commitment or equity exchange. Finally, an important characteristic of this process is organizational anchoring of the corporate accelerators: SUAs, WLAs, and IPAs are typically set up as separately incorporated entities or separate business units. Instead, the ILA and VCA are project based.

Considering graduation and its "pre-defined time schedule" characteristic, the SUA and WLA have a fixed-term batch, in contrast to the flexible-term batch of all other identified types (ILA, VCA, and IPA). Finally, the corporate accelerator types are characterized in four cases by the execution of a graduation event, but not in the cases of ILAs and VCAs. Figure 1 shows the identified types, illustrating their differences, similarities, heterogeneity, and applicability to diverse corporate exchange and collaboration with start-ups. Additionally, Table 5 summarizes the five corporate accelerator types and their similarities and differences and, consequently, the existing ecosystem builder theme. This also supports incumbents' decision making for accelerator programmes to mutually benefit from cooperating and engaging with start-ups. 
Figure 1: Characterization and demarcation of the identified corporate accelerator types

\section{Illustration of corporate accelerator types}

商

1.1 Acquisition Strategy

1.2 Exclusivity

1.3 Admission-Screening of New Startups

2.3 Completeness

2.3.1 Reactive and Episodic Counselling

2.3.2 Proactive and Episodic Counselling

2.3.3 Continous and Proactive Counselling

2.3.4 Hands on Business Assistance /

Technical Assistance

2.4 Degree of Standardization

2.5 Focus on Industries

2.6 Integration with Core Business Corporation

2.7 Direction of Innovation Flow

2.8 Value Capture

2.9 Organizational Anchoring

3.1 Pre-Defined Time Schedule

3.2 Graduation Event

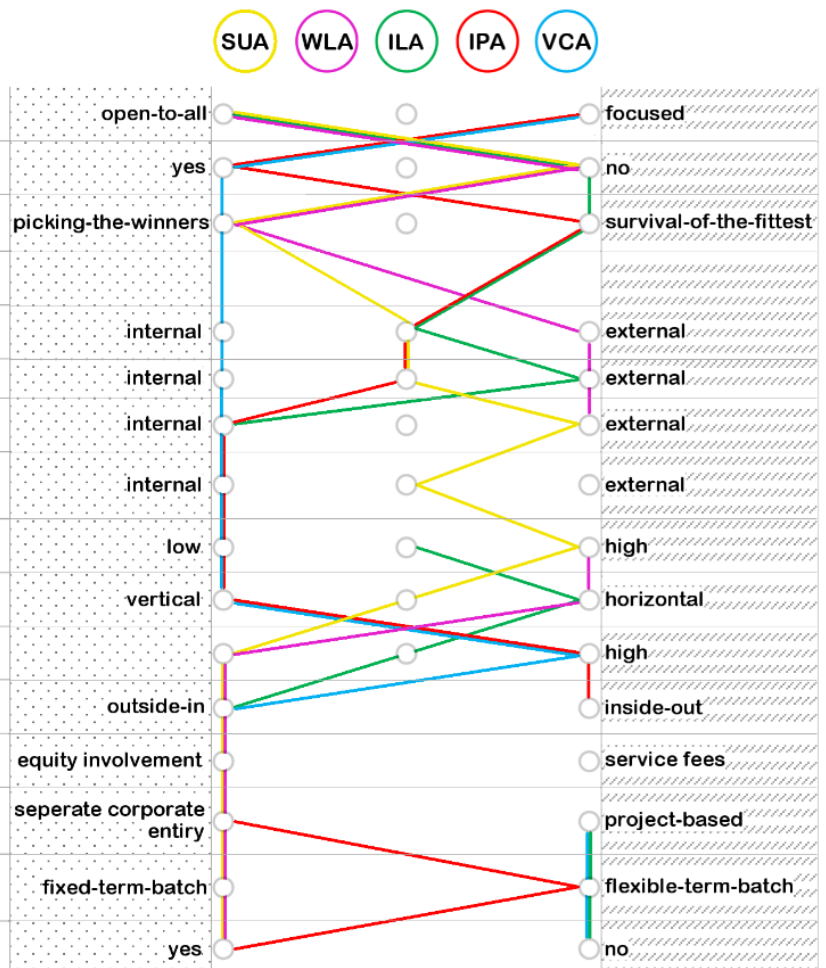

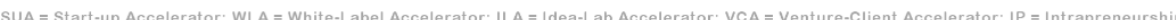

\section{Illustration of the types' heterogeneity}

\begin{tabular}{|c|c|c|c|c|c|}
\hline 1.1 & & & & שiii, & "iIIII) \\
\hline 1.2 & WI// & 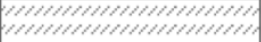 & 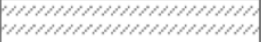 & & \\
\hline 1.3 & & & "IIIIIIIIIII & & "IIIININ) \\
\hline 2.3 .1 & & 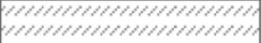 & & & \\
\hline 2.3 .2 & & 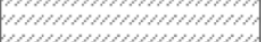 & 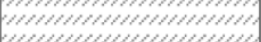 & & \\
\hline 2.3 .3 & 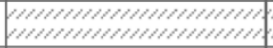 & 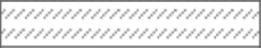 & 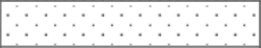 & $\because \because \because \because$ & 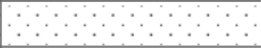 \\
\hline 2.3 .4 & & none / not given & none / not given & & $\therefore$ \\
\hline 2.4 & 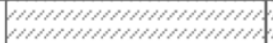 & 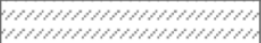 & & & $\because$ \\
\hline 2.5 & & "IIIIIIIIIIIIIIIIIIIIIIIIIIN & 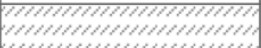 & & \\
\hline 2.6 & & & & 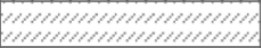 & 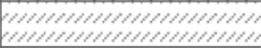 \\
\hline 2.7 & & $\because \because$ & $\because$ & $\because$ & (IIIIIIIIIIIIIIIIIIIIIIIII, \\
\hline 2.8 & & & none / not given & none / not given & none / not given \\
\hline 2.9 & & & 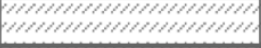 & 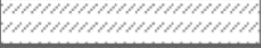 & \\
\hline 3.1 & & & 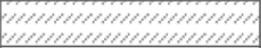 & 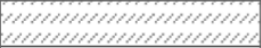 & 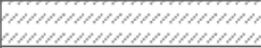 \\
\hline 3.2 & & & (III) & "IIIII & \\
\hline
\end{tabular}


Table 5: Similarities between the five corporate accelerator types and the existing ecosystem builder theme

\begin{tabular}{|c|c|c|c|c|c|}
\hline & $\begin{array}{l}\text { Start-up Accelerator } \\
\text { (SUA) }\end{array}$ & $\begin{array}{c}\text { White-Label } \\
\text { Accelerator (WLA) }\end{array}$ & $\begin{array}{l}\text { Idea-Lab Accelerator } \\
\text { (ILA) }\end{array}$ & $\begin{array}{c}\text { Venture-Client } \\
\text { Accelerator (VCA) }\end{array}$ & $\begin{array}{l}\text { Intrapreneurship } \\
\text { Accelerator (IPA) }\end{array}$ \\
\hline $\begin{array}{l}\text { Short definition of } \\
\text { types in the } \\
\text { ecosystem builder } \\
\text { theme }\end{array}$ & $\begin{array}{l}\text { The modern classical: } \\
\text { Advanced incubator } \\
\text { concept for substantial } \\
\text { relationship and } \\
\text { collaboration with start- } \\
\text { ups, lower risk profile, } \\
\text { and stronger } \\
\text { formalized supporting } \\
\text { process. }\end{array}$ & $\begin{array}{l}\text { The relatively neutral } \\
\text { and adaptable hybrid: } \\
\text { Supported and } \\
\text { facilitated by one or } \\
\text { more corporations with } \\
\text { outsourced partners or } \\
\text { proven expert } \\
\text { providers. Creation of } \\
\text { own ecosystems } \\
\text { around the corporate } \\
\text { involvement in start-up- } \\
\text { supporting activities. }\end{array}$ & $\begin{array}{l}\text { The hands-on active for } \\
\text { the new: Ideas, } \\
\text { experiential futures, } \\
\text { innovation. Providing } \\
\text { possibilities to shape, } \\
\text { adopt, and follow new } \\
\text { trends and weak signals } \\
\text { in corporations from } \\
\text { early on through to the } \\
\text { enactment and beyond. }\end{array}$ & $\begin{array}{l}\text { The exclusive but not } \\
\text { classical engagement } \\
\text { relationship of joint } \\
\text { development: } \\
\text { Corporations aiming to } \\
\text { be the (exclusive) client } \\
\text { or project partner of a } \\
\text { relatively mature start- } \\
\text { up in late-stage } \\
\text { development, helping to } \\
\text { specialize in a specific } \\
\text { industry. }\end{array}$ & $\begin{array}{l}\text { The internal } \\
\text { entrepreneur for high- } \\
\text { level involvement and } \\
\text { integration: Starting } \\
\text { inside the corporation to } \\
\text { accelerate innovation } \\
\text { from within and } \\
\text { depending on the } \\
\text { individual structure and } \\
\text { the employees as the } \\
\text { most important drivers } \\
\text { and (re)sources of the } \\
\text { programme type. }\end{array}$ \\
\hline
\end{tabular}

Ecosystem builder design elements:

\begin{tabular}{|c|c|c|c|c|c|}
\hline $\begin{array}{l}\text { Programme } \\
\text { package of } \\
\text { ecosystem builder }\end{array}$ & $\begin{array}{l}\text { High formalization of } \\
\text { support process, low } \\
\text { integration in core } \\
\text { business, separate } \\
\text { entity } \\
\text { Differences: Incubator- } \\
\text { like direct investments } \\
\text { in new ventures in later } \\
\text { stages, outside-in } \\
\text { innovation flow }\end{array}$ & $\begin{array}{l}\text { High formalization of } \\
\text { support process but } \\
\text { also flexible, individual } \\
\text { approach, low } \\
\text { integration in core } \\
\text { business, separate } \\
\text { entity } \\
\text { Differences: } \\
\text { Equity involvement, } \\
\text { outside-in innovation } \\
\text { flow }\end{array}$ & $\begin{array}{l}\text { Medium formalization of } \\
\text { support process, steady } \\
\text { and more flexible } \\
\text { fluctuation, medium } \\
\text { degree of integration in } \\
\text { core business, project- } \\
\text { based } \\
\text { Differences: } \\
\text { Pre-seed start-up } \\
\text { support of programmes } \\
\text { and early ideas, } \\
\text { outside-in innovation } \\
\text { flow }\end{array}$ & $\begin{array}{l}\text { Low formalization of } \\
\text { support process, high } \\
\text { integration in core } \\
\text { business, project-based } \\
\text { Differences: } \\
\text { Outside-in innovation } \\
\text { flow }\end{array}$ & $\begin{array}{l}\text { Low-to-medium } \\
\text { formalization of support } \\
\text { process, } \\
\text { individualization, and } \\
\text { flexibility; high } \\
\text { integration in core } \\
\text { business, project-based } \\
\text { Differences: } \\
\text { Inside-out innovation } \\
\text { flow }\end{array}$ \\
\hline
\end{tabular}




\begin{tabular}{|c|c|c|c|c|c|}
\hline $\begin{array}{l}\text { Strategic focus of } \\
\text { ecosystem builder }\end{array}$ & $\begin{array}{l}\text { International } \\
\text { vertical/horizontal } \\
\text { focus on industries } \\
\text { Differences: } \\
\text { Local and/or } \\
\text { international }\end{array}$ & $\begin{array}{l}\text { International horizontal } \\
\text { focus on industries } \\
\text { Differences: } \\
\text { Local and/or } \\
\text { international }\end{array}$ & $\begin{array}{l}\text { International horizontal } \\
\text { focus on industries } \\
\text { Differences: } \\
\text { Local and/or } \\
\text { international }\end{array}$ & $\begin{array}{l}\text { International vertical } \\
\text { focus on industries } \\
\text { Differences: } \\
\text { Local and/or } \\
\text { international }\end{array}$ & $\begin{array}{l}\text { International vertical } \\
\text { focus on industries } \\
\text { Differences: } \\
\text { Local and/or } \\
\text { international }\end{array}$ \\
\hline $\begin{array}{l}\text { Selection process } \\
\text { of ecosystem } \\
\text { builder }\end{array}$ & $\begin{array}{l}\text { Favour new ventures in } \\
\text { later stages with } \\
\text { proven track record } \\
\text { Differences: } \\
\text { Focus on teams and } \\
\text { entrepreneurs, open- } \\
\text { to-all, picking-the- } \\
\text { winners }\end{array}$ & $\begin{array}{l}\text { Favour new ventures in } \\
\text { early and/or later stages } \\
\text { but with proven track } \\
\text { record dependant on } \\
\text { individual type of } \\
\text { programme, focus on } \\
\text { teams and } \\
\text { entrepreneurs } \\
\text { Differences: } \\
\text { Early stages and } \\
\text { individuality, focus on } \\
\text { teams and } \\
\text { entrepreneurs } \\
\text { open-to-all, picking-the- } \\
\text { winners }\end{array}$ & $\begin{array}{l}\text { Favour very young } \\
\text { entrepreneurs and start- } \\
\text { ups } \\
\text { Differences: } \\
\text { Focus on teams and } \\
\text { entrepreneurs, open-to- } \\
\text { all, survival-of-the-fittest }\end{array}$ & $\begin{array}{l}\text { Favour new ventures in } \\
\text { later stages with proven } \\
\text { track record and } \\
\text { fundamental proof of } \\
\text { concept } \\
\text { Differences: } \\
\text { Exclusivity of } \\
\text { cooperation, focus on } \\
\text { teams and } \\
\text { entrepreneurs, focused, } \\
\text { picking-the-winners }\end{array}$ & $\begin{array}{l}\text { Favours screening } \\
\text { employees' new start- } \\
\text { up ideas and projects } \\
\text { Differences: } \\
\text { Exclusivity of } \\
\text { cooperation, focus on } \\
\text { individual } \\
\text { teams/projects, } \\
\text { focused, survival-of-the- } \\
\text { fittest, corporate } \\
\text { objectives }\end{array}$ \\
\hline $\begin{array}{l}\text { Funding structure } \\
\text { of ecosystem } \\
\text { builder }\end{array}$ & $\begin{array}{l}\text { Funding from } \\
\text { corporations }\end{array}$ & $\begin{array}{l}\text { Funding from } \\
\text { corporations } \\
\text { Differences: } \\
\text { Supported by } \\
\text { consultancies/agencies }\end{array}$ & $\begin{array}{l}\text { Funding from } \\
\text { corporations }\end{array}$ & $\begin{array}{l}\text { Funding from } \\
\text { corporations }\end{array}$ & $\begin{array}{l}\text { Funding from } \\
\text { corporations }\end{array}$ \\
\hline $\begin{array}{l}\text { Alumni relations } \\
\text { of ecosystem } \\
\text { builder }\end{array}$ & $\begin{array}{l}\text { Opportunity to build } \\
\text { and alumni } \\
\text { infrastructure } \\
\text { dependant on } \\
\text { individual type } \\
\text { Differences: } \\
\text { No special focus }\end{array}$ & $\begin{array}{l}\text { Opportunity to build and } \\
\text { alumni infrastructure } \\
\text { dependant on individual } \\
\text { type } \\
\text { Differences: } \\
\text { No special focus }\end{array}$ & $\begin{array}{l}\text { Opportunity to build and } \\
\text { alumni infrastructure } \\
\text { dependant on individual } \\
\text { type } \\
\text { Differences: } \\
\text { No special focus }\end{array}$ & $\begin{array}{l}\text { Opportunity to build and } \\
\text { alumni infrastructure } \\
\text { dependant on individual } \\
\text { type } \\
\text { Differences: } \\
\text { No special focus }\end{array}$ & $\begin{array}{l}\text { Opportunity to build and } \\
\text { alumni infrastructure } \\
\text { dependant on individual } \\
\text { type } \\
\text { Differences: } \\
\text { No special focus }\end{array}$ \\
\hline
\end{tabular}




\section{DISCUSSION AND IMPLICATIONS}

This study presents further evidence for the dynamically evolving landscape of corporate accelerator programmes as indicated by the rapid growth of new kinds of accelerators and diverse models of corporate engagement with start-ups. The results support the assumptions that (1) there is heterogeneity among corporate accelerator programmes based on differences in the three-step process of selection, business support, and graduation, and (2) the heterogeneity among different corporate accelerator programmes leads to different types within the ecosystem builder theme.

Some corporate accelerator programmes and types follow a stronger specialist approach with a vertical industry focus, whereas others aim for a wide variety of start-up ideas within their portfolio. In addition, some corporate accelerators confirm that the first batch of their programme was a learning phase and that they wanted to teach, learn, and develop further entrepreneurial spirit within their corporation to bridge the gap between both worlds (corporations and start-ups). Besides the typical trial-and-error approach of testing processes inside the programme, the important factors for the programmes were reputation building and accepting collaboration in the start-up ecosystem.

However, our findings also support a numerical increase in programmes and the emergence of hybrid types of the ecosystem builder theme. Because of the varying corporate structures, diverse attitudes, and the individual, dynamic environments of incumbent corporations, corporate accelerators may vary their start-up-supporting services or design elements (see Tables 3 and 4 and Figure 1). Moreover, the emergence of White-Label Accelerators shows that an independent ecosystem (comprising consulting firms and agencies) is forming around corporate involvement in start-up-supporting activities and is engaging in general innovation (Hochberg, 2016; Kohler, 2016; Weiblen \& Chesbrough, 2015).

\section{Theoretical Implications}

Within the fragmented work on accelerator programmes, this study provides a first step in integrating and connecting existing and new research to achieve the following: (1) provide a 
consistent and systematic theoretical understanding about corporate accelerators, their strategies, design elements, and processes (Hochberg, 2016; Pauwels et al., 2016; Weiblen \& Chesbrough, 2015); (2) improve understanding of the new-generation incubation models with a more detailed and informed image of how to specify their accelerator programmes; (3) extend Pauwels et al.'s (2016) study by emphasizing the components of the corporate accelerator programmes in the ecosystem builder theme using a process-based approach to complement their design approach and to ease the positioning in the ecosystem; and (4) complement the categorization of the different models of activity systems (Amit \& Zott, 2012) depending on the different elements and characteristics.

\section{Managerial Implications}

By reducing the complexity of the programmes and facilitating their selection, incumbents can use this open innovation strategy to access start-up ecosystems and develop them according to their strategic objectives (Weiblen \& Chesbrough, 2015). In particular, corporate objectives linked to ecosystem building (e.g., growing agility of business models and strategies to enter new industries and implement new technological environments and/or generate access to the "new digital age" of business) represent the critical starting point for decision-making about the selection process and the strategic focus, among other things. Corporations can use the three-step process and the five types and their corresponding characteristics as a guideline (1) to develop their startup engagement; (2) to use, design, and position their individual accelerator programmes; and (3) to grow the corporation's and the individual's perception of the future and an agile long-term corporate strategy.

Our research shows that accelerator programmes vary in their strategic objectives; thus, companies need to understand what they can achieve with a particular programme. The industrial focus, integration with the corporation's core business, direction of innovation flow, and organizational anchoring are representative characteristics of heterogeneity and important drivers for the distinction of accelerator programmes. From our research, we distilled the following exemplary factors that may guide corporate decision making about engagement and collaboration 
with start-ups and entrepreneurs in the first step: the maturity of the idea, the possible time horizon (long- or short-term engagement and batches) in relation to organizational anchoring (separate or project based), and industry focus (vertical or horizontal).

Considering this with the existing corporate activities to push innovation (internally and/or externally) and the respective patience for countable results yields the following implications: (1) for Idea-Lab Accelerator (ILA), corporations seek a long engagement perspective with a horizontal industry focus. It is project-based in the first step and favours very young but also mature ideas and entrepreneurs of all levels of experience with an outside-in innovation flow. (2) The VentureClient Accelerator (VCA) focuses on later-stage, mature, and experienced start-ups within their own market space (vertical approach). It favours a high degree of integration in corporate core business but a low degree of standardization to allow flexible collaboration and an exclusive developmental relationship with the start-ups. (3) For example, a corporation fosters its employees' start-up projects at all experience levels, establishing them in a separate corporate entity or business unit, adopting a vertical focus on industries, and favouring an outside-in innovation. Here, the corporation follows the Intrapreneurship Accelerator type and fosters individualization and flexibility in the acceleration process to push and pull innovation in the corporation.By identifying cases in each type from different industries, we conclude that accelerator programmes are not restricted to one industry.

\section{LIMITATIONS, FUTURE RESEARCH, AND CONCLUSION}

The five accelerator types within the ecosystem builder design theme (Pauwels et al., 2016) are a fruitful starting point for elaborating their content, characteristics, similarities, differences, and mechanisms of their engagement (strategies, design elements and processes). They generate insights into the structure and organization to set up ecosystem builder accelerator types. However, the present study also reveals some limitations and future research opportunities.

First, because our research focuses on corporate accelerators in Germany, the research scope should extend to other countries and explore the influence of different cultural, economic, political, and administrative contexts. Second, although the proposed typology can serve as a 
basis for future research, it is necessary to continuously examine, expand, and adapt it to changing corporate structures, cultures, and environments and the evolution of new types of corporate accelerators. Third, this research could be completed by new evaluation phases, providing insights into the success of corporate accelerator types and their different strategies, exploring future transformations of accelerator programmes due to further developments and improvements, and seeking results beyond purely financial returns. Fourth, the dynamic and volatile developments in this market mean that the strategies of the observed corporate accelerator types vary and thus need to be continuously reviewed, adapted, and systematized. New accelerator types and diverse models of corporate engagement with start-ups and ecosystems will likely emerge. Fifth, in addition to the company's point of view, research could also explore the views of diverse start-ups associated with corporate accelerator programmes.

We hope that this study enriches our understanding of how to make strategically informed decisions about suitable accelerator programmes and that it stimulates further research into this important topic. 


\section{REFERENCES}

Allen, D. N. and McCluskey, R. (1990) Structure, policy, services, and performance in the business incubator industry. Entrepreneurship Theory and Practice, 15, 2, 61-77.

Amit, R. and Zott, C. (2012) Creating Value Through Business Model Innovation. MIT Sloan Management Review, 53, 3.

Barbero, J. L., Casillas, J. C., Wright, M., and Garcia, A. R. (2014) Do different types of incubators produce different types of innovations? Journal of Technology Transfer, 39, 2, 151-168.

Bauer, S., Obwegeser, N., and Avdagic, Z. (2016) Corporate accelerators: Transferring technology innovation to incumbent companies. MCIS 2016 Proceedings, Paper 57.

Baum, J. A. and Silverman, B. S. (2004) Picking winners or building them? Alliance, intellectual, and human capital as selection criteria in venture financing and performance of biotechnology startups. Journal of Business Venturing, 19, 411-436.

Benson, D. and Ziedonis, R. H. (2009) Corporate venture capital as a window on new technologies: implications for the performance of corporate investors when acquiring startups. Organization Science, 29, 2, 329-351.

Bergek, A. and Norrman, C. (2008) Incubator best practice: A framework. Technovation, 28, 2028.

Bernard, H. R. and Bernard, H. R. (2012) Social Research Methods: Qualitative and Quantitative Approaches. Thousand Oaks, CA: Sage.

Bruneel, J., Ratinho, T., Clarysse, B., and Groen, A. (2012) The evolution of business incubators: Comparing demand and supply of business incubation services. Technovation, 31, 110121.

Cohen, S. L. (2013) What do accelerators do? Insights from incubators and angels. Innovations: Technology, Governance, Globalization, 8, 3-4, 19-25.

Cohen, W. M. and Levinthal, D. A. (1990) Absorptive capacity: A new perspective on learning and innovation. Administrative Science Quarterly, 35, 1, 128-152.

DaSilva, C. M. and Gurtner, P. (2017) Accelerators: An assessment of acceleration models. Academy of Management Annual Meeting Proceedings, January 2017, 1, 1. 
Eisenhardt, K. (1989) Building Theories from case study research. Academy of Management Review, 14, 4, 532-550.

Eisenhardt, K. M. and Graebner, M. E. (2007) Theory building from cases: Opportunities and challenges. Academic Management Journal, 50, 1, 25-32.

Enkel, E., Gassmann, O., and Chesbrough, H. (2009) Open R\&D and open innovation: Exploring the phenomenon. R\&D Management, 39, 4, 311-316.

Gassmann, O., Enkel, E., and Chesbrough, H. (2010) The future of open innovation as a researchable theory. $R \& D$ Management, 40, 3, 213-221.

Gioia, D. A., Price, K. N., Hamilton, A. L., and Thomas, J. B. (2010) Forging an identity: An insideroutsider study of processes involved in the formation of organizational identity. Administrative Science Quarterly, 55, 1, 1-46.

Grimaldi, R. and Grandi, A. (2005) Business incubators and new venture creation: An assessment of incubating models. Technovation, 25, 2, 111-121.

Hackett, S. M. and Dilts, M. D. (2004) A systematic review of business incubation research. Journal of Technology Transfer, 29, 55-82.

Heinemann, F. (2016) Database of Corporate Accelerators. Available at: https://www.corporateaccelerators.net/database/index.html.

Hochberg, Y. V. (2016) Accelerating entrepreneurs and ecosystems: The seed accelerator model. Innovation Policy and the Economy, 16, 1, 25-51.

Irvine, A., Drew, P., and Sainsbury, R. (2013) 'Am I not answering your questions properly?' Clarification, adequacy and responsiveness in semi-structured telephone and face-to-face interviews. Qualitative Research, 13, 1, 87-106.

Isabelle, D. A. (2013) Key factors affecting a technology entrepreneur's choice of incubator or accelerator. Technology Innovation Management Review, 3, 2, 16-22.

Kohler, T. (2016) Corporate accelerators: Building bridges between corporations and startups. Business Horizons, 59, 3, 347-357. 
McAdam, M. and McAdam, R. (2008) High tech start-ups in University Science Park incubators: The relationship between the start-up's lifecycle progression and use of the incubator's resources. Technovation, 28, 5, 277-290.

McLellan, E., MacQueen, K. M., and Neidig, J. L. (2003) Beyond the qualitative interview: Data preparation and transcription. Field methods, 15, 1, 63-84.

Mian, S., Lamine, W., and Fayolle, A. (2016) Technology business incubation: An overview of the state of knowledge. Technovation, 50-51, April-May 2016, 1-12.

Miles, M. B. and Huberman, A. M. (1994) Qualitative Data Analysis: An Expanded Sourcebook (2nd ed.). Thousand Oaks, CA: Sage Publications.

Miller, P. and Bound, K. (2011) The Startup Factories: The Rise of Accelerator Programmes to Support New Technology Ventures. London: Nesta.

Oh, D. S., Phillips, F., Park, S., and Lee, E. (2016) Innovation ecosystems: A critical examination. Technovation, 54, 1-6.

Pauwels, C., Clarysse, B., Wright, M., and Van Hove, J. (2016) Understanding a new generation incubation model: The accelerator. Technovation, 50, 13-24.

Pinchot, G. (1985) Intrapreneuring - Why You Don't Have to Leave the Corporation to Become an Entrepreneur. New York: Harper \& Row Publishers.

Rice, M. P. (2002) Co-production of business assistance in business incubators: An exploratory study. Journal of Business Venturing, 17, 2, 163-187.

Schwartz, M. (2013) A control group study of incubators' impact to promote firm survival. Journal of Technology Transfer, 38, 3, 302-331.

Spiggle, S. (1994) Analysis and interpretation of qualitative data in consumer research. Journal of Consumer Research, 21, 3, 491-503.

Stuart, T. E., Hoang, H., and Hybels, R. C. (1999) Interorganizational endorsements and the performance of entrepreneurial ventures. Administrative Sciences, 44, 315-349.

Vanderstraeten, J. and Matthyssens, P. (2012) Service-based differentiation strategies for business incubators: Exploring external and internal alignment. Technovation, 32, 656-670. 
Volberda, H. W., Foss, N. J., and Lyles, M. A. (2010) Absorbing the concept of absorptive capacity: How to realize its potential in the organization field. Organization Science, 21, 4, 931-951.

Weiblen, T. and Chesbrough, H. (2015) Engaging with startups to enhance corporate innovation. California Management Review, 57, 2, 66-90.

Welter, F. (2011) Contextualizing entrepreneurship - conceptual challenges and ways forward. Entrepreneurship: Theory \& Practice, 35, 1, 165-184.

Wise, S. and Valliere, D. (2014) The impact on management experience on the performance of start-ups within accelerators. Journal of Private Equity, 18, 1, 9-19.

Yin, R. K. (2013) Case Study Research: Design and Methods (3rd ed.). Thousand Oaks, CA: Sage Publications. 